\title{
滋賀県における温暖化条件でのニカメイガ発生様相と 防除適期の推測
}

\author{
那須大城・江波義成 \\ (滋賀県農業技術振興センター)
}

気象庁の予測では, 温暖化が進行し, 今後100年で日 本の年平均気温は $2 \sim 3^{\circ} \mathrm{C}$ 上昇するといわれる。この温 暖化が農業昆虫に与える影響についてはさまざまな研究 が行われており，1）分布域の北上，2）冬期死亡率の低 下，3）春の発生開始時期の早期化，4）年間世代数の増 加が予想されている ${ }^{2)}$ 。年間世代数については昆虫の発 育零点と有効積算温度から求めることができ, 年平均気 温が $15^{\circ} \mathrm{C}$ の地点で気温が $2^{\circ} \mathrm{C}$ 上昇した場合, 水田害虫 の年間世代数は 1 世代増加するといわれる

かつて重要害虫であったニカメイガは，全国的には 「ただの虫」と化している。しかしながら, 滋賀県では 近年増加傾向にあり，2009年には滋賀県病害虫防除所か ら本種に関する病害虫発生予察注意報が40年ぶりに発表 され，2010年にも続けて発表されている。今後，温暖化 が進むに従って, 二カメイガの発生様相は発生時期の早 期化と世代数の増加等が想定される。そこで, 温暖化に 伴う滋賀県におけるニカメイガの発生様相を推測し, そ れに対応した防除適期を推測した。なお，二カメイガ は地域の気候等に適応し生態を変化させている ら, 太平洋側気候である滋賀県南部と日本海側気候であ る滋賀県北部に分けて推測した。

\section{材料および方法}

滋賀県病害虫防除所予察灯観測データ（昭和51年〜平 成20年）を基にして，ニカメイガの成虫発生ピークが明 瞭な二山型を示す10か年を選び，そのピーク日を読み 取った。二カメイガ越冬幼虫は 2 月に休眠から覚醒する ため, 2 月 1 日から最初のピーク日までの時別気温（1 時間ごとの平均気温）について発育零点を $10^{\circ} \mathrm{C}^{3)}$ とし て積算し，10か年分の平均から越冬世代の有効積算温度 を求めた。二カメイガは羽化後すぐ交尾し翌日には産卵 する4) ため，二つのピーク間の時別気温について発育零
点を $10^{\circ} \mathrm{C}^{3)}$ として積算し, 10 年分の平均から第 1 , 第 2 世代の有効積算温度を求めた。第 2 世代幼虫の休眠の 誘起については, 幼虫期の日長が影響していることから, 推測されたふ化日の日長が岸野 $(1974)^{3)}$ で示された休 眠誘起臨界日長以下であれば休眠するとした。すなわち, 県南部のニカメイガはふ化時の日長が14.1時間以下, 県 北部は14.25時間以下で休眠する ${ }^{3)}$ として, 国立天文台 ホームページよりその月日を求めた。なお, 時別気温か ら積算する有効積算温度の計算は, 昆虫の世代推定モデ ル を) を利用した。また, 予察灯観測データは, 県南部と して近江八幡市安土町, 県北部として長浜市木之本町の 観測データを用い, 世代推定モデルに利用したアメダス データは, 予察灯設置場所に近い彦根および虎姫の 2 地 点のデータを用いた。

ニカメイガ発生様相の推測は, 平年值とそれより $1^{\circ} \mathrm{C}$, $2^{\circ} \mathrm{C}, 3^{\circ} \mathrm{C}$ 上昇した場合について行った。なお平年值は, 気像観測統計指針による累年平均值（昭和46年から平成 12年の30年間の平均值）を用いた。

推測した第 1 世代発蛾最盛日より, 第 2 世代の幼虫防 除適期を求めた。防除適期は, 滋賀県農作物病害虫雑草 防除基準 ${ }^{5)}$ より第 1 世代発蛾最盛日から 7 日後とした。 加えて, 滋賀県水稲生育診断プログラムを用いて, 滋賀 県における水稲の出穂期を推測し, 推測した二カメイガ の防除適期との関係を検討した。出穂期の推測にあたっ ては, 水稲移植日は 5 月 10 日とし, 水稲の品種は「コシ ヒカリ」および「日本晴」とした。

\section{結果および考察}

滋賀県におけるニカメイガの生態的パラメーターとし て, 発育零点を設定し, 有効積算温度と休眠誘起の臨界 ふ化時期を推定した（第 1 表）。第 1 , 第 2 世代の有効 積算温度は, 県南部が799.1日度, 県北部が741.0日度で

Hiroki Nasu and Yoshinari Enami (Shiga Pref. Agr. Tech. Prom. Ctr.): Predicted effect of global warming on the occurrence of rice stem borer (Chilo suppressalis) in Shiga Prefecture 2011年 2 月11日受理 
第 1 表 滋賀県におけるニカメイガの生態的パラメーター

\begin{tabular}{|c|c|c|c|}
\hline 推測する項目 & $\begin{array}{l}\text { パラメーター } \\
\left({ }^{\circ} \mathrm{C}, \text { 日度 }\right)\end{array}$ & $\begin{array}{l}\text { 県南部 } \\
\text { (安土) }\end{array}$ & $\begin{array}{l}\text { 県北部 } \\
\text { (多本) }\end{array}$ \\
\hline \multirow{2}{*}{$\begin{array}{l}\text { 越冬世代 } \\
\text { 発蛾最盛日 }\end{array}$} & 発育零点 & 10.0 & 10.0 \\
\hline & $\begin{array}{l}\text { 2/1からの } \\
\text { 有効積算温度 }\end{array}$ & 320.5 & 344.4 \\
\hline \multirow{2}{*}{$\begin{array}{l}\text { 第 } 1 \text {, 第 } 2 \text { 世代 } \\
\text { 発蛾最盛日 }\end{array}$} & 発育零点 & 10.0 & 10.0 \\
\hline & 有効積算温度 & 799.1 & 741.0 \\
\hline $\begin{array}{l}\text { 第 } 2 \text { 世代 } \\
\text { 休眠誘起 }\end{array}$ & $\begin{array}{l}\text { 休眠誘起の } \\
\text { 臨界ふ化時期 }\end{array}$ & $7 / 25$ & $7 / 19$ \\
\hline
\end{tabular}

あり，岸野（1974）で示された570～825日度 ${ }^{3)}$ の範囲内 であった。

推測されたニカメイガの発蛾最盛日は, 気温が $1^{\circ} \mathrm{C}$ 上 昇すると県南部では 6 日，県北部では 7 日早くなった (第 2 表)。また，県南部では $2^{\circ} \mathrm{C}$ 上昇すると第 2 世代発 蛾最盛日が出現し, 次世代の発生により世代数は増加す

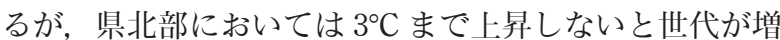
加しないと推測された（第 2 表）。

推測された水稲の出穂日は気温の上昇とともに早くな る(第 3 表)。二カメイガ第 2 世代幼虫の防除適期も気 温の上昇とともに早くなるが，その程度は出穂期と比べ て，より大きい。たとえば，「コシヒカリ」の場合，気 温が平年值では防除適期は県南部で出穂の 6 日後, 県北 部で 4 日後であるが，県南部で $3^{\circ} \mathrm{C}$ ，県北部で $2^{\circ} \mathrm{C}$ 上昇 すると防除適期は出穂より前となる（第 3 表）。滋賀県 での本田害虫防除は，主に斑点米カメムシ類を対象とし て行われ, 二カメイガも同時防除されていることが多い。 斑点米カメムシ類の防除適期は，加害が始まる水稲出穂 後であるため, 温暖化で早まったニカメイガの防除適期 とずれが生じ同時防除できなくなる可能性が高い。「日 本晴」の場合は，気温がどの条件でも防除適期が水稲の 出穂より前となると推測された（第 3 表）。防除適期は 二カメイガのふ化幼虫が水稲に食入する時期でもある。 二カメイガ第 2 世代幼虫の食入が，水稲の出穂前である と幼虫の生存率が高まる1) ため,「コシヒカリ」で気温 が $2 \sim 3^{\circ} \mathrm{C}$ 上昇した場合は，中生の「日本晴」と同様に， 被害がより発生しやすいと考えられた。
第 2 表 推測した有効積算温度による各世代の発蛾最盛日

\begin{tabular}{|c|c|c|c|c|}
\hline 地域 & 気温 & 越冬世代 & 第 1 世代 & 第 2 世代 \\
\hline \multirow{4}{*}{$\begin{array}{l}\text { 県南部 } \\
\text { (安土) }\end{array}$} & 平年值 & 6 月 2 日 & 7 月 $31 日$ & 休眠 \\
\hline & $+1^{\circ} \mathrm{C}$ & 5 月 27 日 & 7 月 25 日 & 休眠 \\
\hline & $+2^{\circ} \mathrm{C}$ & 5 月 21 日 & 7 月18日 & 8 月 29 日 \\
\hline & $+3^{\circ} \mathrm{C}$ & 5 月 15 日 & 7 月 12 日 & 8 月 22 日 \\
\hline \multirow{4}{*}{$\begin{array}{l}\text { 県北部 } \\
\text { (关本) }\end{array}$} & 平年値 & 6 月 6 日 & 8 月 1 日 & 休眠 \\
\hline & $+1^{\circ} \mathrm{C}$ & 5 月30日 & 7 月 25 日 & 休眠 \\
\hline & $+2^{\circ} \mathrm{C}$ & 5 月 24 日 & 7 月19日 & 休眠 \\
\hline & $+3^{\circ} \mathrm{C}$ & 5 月 18 日 & 7 月 12 日 & 8 月 20 日 \\
\hline
\end{tabular}

第 3 表 水稲出穂日と第 2 世代幼虫防除適期の推測

\begin{tabular}{|c|c|c|c|c|}
\hline \multirow{2}{*}{ 地域 } & \multirow{2}{*}{ 気温 } & \multicolumn{2}{|c|}{ 水稲出穂日 } & \multirow{2}{*}{ 防除適期 } \\
\hline & & コシヒカリ & 日本晴 & \\
\hline \multirow{4}{*}{$\begin{array}{l}\text { 県南部 } \\
\text { (安土) }\end{array}$} & 平年值 & 8 月 1 日 & 8 月 9 日 & 8 月 7 日 \\
\hline & $+1^{\circ} \mathrm{C}$ & 7 月27日 & 8 月 4 日 & 8 月 1 日 \\
\hline & $+2^{\circ} \mathrm{C}$ & 7 月24日 & 7 月 31 日 & 7 月 25 日 \\
\hline & $+3^{\circ} \mathrm{C}$ & 7 月21日 & 7 月 $27 日$ & 7 月 19 日 \\
\hline \multirow{4}{*}{$\begin{array}{c}\text { 県北部 } \\
\text { (杢之本) }\end{array}$} & 平年值 & 8月 4 日 & 8 月 18 日 & 8 月 8 日 \\
\hline & $+1^{\circ} \mathrm{C}$ & 7 月31日 & 8 月 $11 日$ & 8 月 1 日 \\
\hline & $+2^{\circ} \mathrm{C}$ & 7 月27日 & 8 月 4 日 & 7 月 26 日 \\
\hline & $+3^{\circ} \mathrm{C}$ & 7 月23日 & 7 月 31 日 & 7 月19日 \\
\hline
\end{tabular}

ニカメイガの発生量に関しては今回検討していない が，2050年頃には現在の1.6倍に増えるという予測 ${ }^{8)}$ が ある。このことからも, 二カメイガは温暖化に伴って被 害増加が危惧される害虫といえる。

\section{引用文献}

1) 平野千里 (1964) 応動昆 8(2) : 166-169.

2）桐谷圭治（1999）研究ジャーナル 22(4)：29-35.

3）岸野賢一（1974）東北農試研報 $47: 13-114$.

4）野里和雄（1981）応動昆 25(4)：213-218.

5）滋賀県（2010）平成22年度滋賀県農作物病害虫雑草防除基 準. http://www.pref.shiga.jp/g/kodawari/nouyaku/20kijun.html

6）田中 慶（1997）Javaによる作物生育・病害虫発生予測乇 デル. http://cse.naro.affrc.go.jp/ketanaka/model/

7) Yamamura, K. and K. Kiritani (1998) Appl. Entomol. Zool. 33: 289-298.

8) Yamamura, K., M. Yokozawa, M. Nishimori, Y. Ueda and T. Yokosuka (2006) Popul. Ecol. 48: 31-48. 